\author{
열처리를 달리한 시유의 전자코 분석 \\ 홍은정 · 노봉수 · 박승용 ${ }^{1 *}$ \\ 서울여자대학교 식품공학과, ${ }^{1}$ 천안연암대학교 축산계열
}

\title{
Analysis of the Different Heated Milks using Electronic Nose
}

\author{
Eun-Jeung Hong, Bong-Soo Noh, and Seung-Yong Park ${ }^{1 *}$ \\ Department of Food Science and Technology, Seoul Women's University, Seoul 139-774, Korea \\ ${ }^{1}$ Department of Animal Science, Cheonan Yonam College University, Cheonan 331-709, Korea
}

\begin{abstract}
This study was conducted to investigate the application of a model system using an MS-electronic nose based on the discriminative function analysis on volatile flavors, to prediction of the shelf-life of market milk by preservation temperature and differently-loaded heat treatment. On mass spectrum, the ion fragments of volatile flavors of milk obtained from MSelectronic nose could be distinguished at amu 60,91, 92, and 93. The response levels of volatile flavors at each amu increased in proportion to the heat treatment loaded to the milk, in the order of LTLT, HTST, and UHT. This study indicated that the discriminative function scores of the volatile flavors seemed to correlate with the preservation temperature, storage period, and heat treatment conditions; DF1 (discriminative function first score) showed a strong relationship to storage periods, with $\mathrm{r}^{2}$ of $0.9965,0.9965$, and 0.9911 at temperatures of 4,7 , and $10^{\circ} \mathrm{C}$, respectively, while DF2 was influenced by heat treatment conditions with an $r^{2}$ of 0.9861 at $4^{\circ} \mathrm{C}$. It is suggested that the discriminative function analysis given by an MSelectronic nose could be used to construct a new quality control model system for the evaluation of heat treatment loaded during the processing of milk, and for predicting storage periods of market milk.
\end{abstract}

Key words: MS-electronic nose system, discriminative function analysis (DFA), market milk, prediction of shelf-life, preservation temperature

\section{서 론}

시유의 품질을 결정하는 요인에는 맛, 향, 색, 등의 관 능적 품질과 영양학적 품질, 그리고 미생물학적 품질 등 여러 가지가 있는데 그 중에서도 특히 풍미가 품질결정에 중요하다. 그 이유는 여러 요인들 중에서 풍미가 저하되 면 상품성이 낮아지기 때문이다. Chung 등(2002)에 의하 면 시유를 $5,10,15^{\circ} \mathrm{C}$ 로 나누어 15 일간 미생물을 측정한 결과 모든 저장 온도에서 일반 세균수는 기준치 이하였으 며 저온성 세균수와 대장균군 역시 검출되지 않거나 안전 한 수준이었다. 관능검사에서도 초기에는 이미 이취가 감 지되지 않았으나 15 일째에 미세한 이미 이취가 감지되었 다. 이러한 결과는 품질상의 하자가 없으나 풍미에 미세 한 차이가 생긴 것으로 보아 우유의 품질 검사에는 이화

*Corresponding author: Seung-Yong Park, Department of Animal Science, Cheonan Yonam College University, Cheonan 331-709, Korea. Tel: 82-41-580-1082, Fax: 82-41-580-1241, E-mail: sypark@yonam.ac.kr
학적 검사나 미생물 검사, 관능검사 등 한 가지 방법이 아 닌 여러 가지 방법이 복합적으로 이루어져야 하는 것으로 판단된다.

식품의 변질 정도를 측정하는 방법으로는 주관적인 방 법과 객관적인 방법으로 구분할 수 있는데 주관적인 방법 의 경우 관능검사가 대표적이다. 이 방법은 패널들을 많 이 훈련시켜 복합적인 향의 강도나 배합의 차이를 감지한 다는 장점이 있다. 하지만 개인적인 차이와 식별능력의 차 이, 표현 방법의 차이 등 객관성이 떨어질 우려가 있으며 (Choi, 1995) 재현성 있는 결과를 얻기 힘들고 후각이 쉽 게 피로해진다는 단점이 있다(Vincent, 1999). 또한 저장 실험의 경우 변질되거나 변질 우려가 있을 경우 지속적으 로 관능검사를 하기에는 한계가 있고 저장 초기값을 기억 하여 비교하는데 어려움이 있으며 매번 약간의 변화가 예 상되는 대조구를 통하여 비교하는 등의 한계점으로 인하 여 관능검사 한가지만으로는 품질관리에 어려움이 있다. 반면 물성적, 이화학적, 미생물학적 방법, 기기분석 방법 등은 객관적(Hodgins and Simmonds, 1995)이기는 하지만 
그 과정이 복잡하고 많은 시간을 필요로 한다. 기기 분석 방법 중 하나인 $\mathrm{GC}$ 나 $\mathrm{GC} / \mathrm{MS}$ 의 경우 식품 내의 각 성분 들로 인한 향의 특성을 표현할 수 없는 제약이 있으며 전 처리가 복잡하고 비교적 오랜 시간이 걸린다(Barlet et al., 1997). 또한 전처리 과정 중에 용매 추출을 할 경우 기존 성분이 손실될 가능성이 있으며, 관능적인 면과는 차이가 있을 수 있다. 따라서 이를 보완하기 위하여 사람의 코처 럼 미묘하고 복잡한 향과 냄새성분을 감지할 수 있는 객 관적인 전자코 시스템의 활용이 효과적이다.

Moseley keeping-quality test(Elliker et al., 1964)와 같은 45년 이상 전통적으로 실시해 온 미생물 시험법의 경우 장기간의 배양시간이 소요되며, 법적인 기준치 이하에서 미세한 변질이 시작되어도 그러한 변화를 미생물 분석에 의하여 해석하거나 즉각적으로 가공현장에 도움을 주기에 는 어려운 점을 내포하고 있다(White et al., 2006).

시유의 풍미는 저장조건이나 미생물에 의한 작용, 화학 적 변화, 이물질의 유입 등에 의하여 영향을 받으며 일반 적으로 산패취나 산화취에 의하여 좌우되는데 Chung 등 (2008)은 다양한 우유 품목의 관능적 성질과 전자코로 분 석한 향기 패턴 간에 상호 관련성이 높음을 암시한바 있 어 주관적인 검사와 객관적인 분석간의 한계점을 전자코 가 보완해 줄 수 있음을 제시한바 있다.

Yang 등 $(1999)$ 은 $4,15,30^{\circ} \mathrm{C}$ 에서 시유를 저장 보관하면 서 $\operatorname{MOS}$ (metal oxide sensor)-전자코를 이용하여 품질을 분 석한 결과 $\mathrm{pH}$, 산도의 변화와 유사하게 나타나 우유의 신 선도 측정을 전자코로 예측하는 것이 가능함을 보여주었 다. 상대적인 변화를 예측하는데 큰 무리가 없으나 MOS전자코의 경우 metal oxide센서의 내구성이 제한되어 있 고 초기 측정값이 시간이 경과함에 따라 조금씩 변화하기 때문에 이에 대한 보정 작업이 별도로 요구되며 센서마다 선택성이 뛰어나지 못하여 정량적인 분석에는 한계점을 안고 있다.

우유를 $5^{\circ} \mathrm{C}$ 에서 52 일동안 저장하면서 변화를 $\operatorname{MOS}$ 전 자코로 분석한 결과 시간이 지남에 따라 변화되는 차이를 구분할 수 있는데 이 결과는 미생물 실험 결과와도 유사 한 경향을 보여주기도 하였고(Said et al., 2005), 두유에서 나는 이취를 최소화하기 위하여 cyclodextrin(CD)을 농도 와 저장 기간을 달리하여 결합하게 한 후 $\mathrm{GC}$ 를 바탕으로 한 전자코를 통해 $\mathrm{CD}$ 농도가 높을수록 두유의 이취 원인 물질인 hexanal의 농도가 낮아지는 것을 확인한 바 있다 (Youn, 2007). 한편 두부의 경우에는 저장 온도와 저장 기 간을 달리하여 $\mathrm{MOS}$ 전자코로 분석한 결과 저장온도 별로 kinetics를 통해 반응식을 유도하고 이를 토대로 불규칙한 온도 조건에 저장하였을 때 품질 수명 기간을 예측할 수 있었다(Kim and Noh, 2002). 이 연구에서는 약 7\%정도의 실험 오차를 보였다. 이러한 활용에도 불구하고 $\operatorname{MOS}$ 전자 코의 한계점으로 보이는 정량적인 분석까지도 가능한 전
자코 시스템이 요구되었다. 미세한 변화를 보다 더 정확 히 측정하기 위한 방법으로 개발된 2세대 전자코들은 이 런 문제들이 부분적으로 해결이 되었는데 그 중 하나인 MS-전자코 시스템으로 정량적 분석뿐만 아니라 미량의 시 료 감지 능력까지 갖추고 있어 우유에 오염된 trimethylamine (Ampuero et al., 2002)이나 benzene의 양을 ppb수준까지 측정하는 것이 가능하였다. 따라서 MS-전자코 시스템은 작은 온도 차이를 두고 저장된 우유의 미세한 변화까지도 감지할 수 있어 품질 변화의 예측을 보다 정확하게 예상 할 수 있을 것으로 사료된다.

본 연구에서는 시중에서 판매되고 있는 LTLT, HTST, UHT우유의 가열공정에서 적용한 열처리 정도에 따라 생 성된 휘발성분의 함랑을 전자코 분석기술로 분석하여 우 유에 가해진 열처리 정도를 예측해보고자 하였으며, 또한 보존 온도를 달리하여 저장하는 동안 각 우유에 발생하는 휘발성분의 변화량에 대한 판별함수분석(discriminant function analysis)을 실시하여 휘발성분 변화량과 열처리 정도, 저장기간과의 관련성을 연구하였다.

\section{재료 및 방법}

\section{재료}

국내 매장에서 판매되고 있는 low temperature long time(LTLT) 처리한 우유 1종(B), high temperature short time(HTST) 처리한 우유 3종(A, C, D) 및 ultra high temperature(UHT) 처리한 우유 4종 $(\mathrm{E}, \mathrm{F}, \mathrm{G}, \mathrm{H})$ 등 총 1,728 packs을 대형 마트에서 구입하였다. 우유 시료는 pack을 개봉하지 않은 채로 $4,7,10^{\circ} \mathrm{C}$ 에서 냉장 보관(VS-1203PF$\mathrm{CN}$, Manhattan, USA) 하면서 매 분석 마다 개봉하였으며, $1 \mathrm{~mL}$ 의 우유를 채취하여 $10 \mathrm{~mL}$ vial(Pharma Fix. Chemmea, Slovakia)에 넣은 후 PTFE/silicone 뚜껑으로 밀봉하여 향 기 패턴을 분석하였다.

\section{Electronic Nose 분석}

각 시료가 들어 있는 vial을 $300 \mathrm{rpm}$ 으로 교반하면서 $70^{\circ} \mathrm{C}$ 를 유지하였고 주입구 온도는 $130^{\circ} \mathrm{C}$ 인 상태에서 주 입하였다. 이 때 사용한 가스는 질소(99.999\%)였으며 분 당 $230 \mathrm{~mL}$ 의 유속으로 흘려 보냈다. 데이터 수집시간은 3 분이었으며 분석 후 purge는 3 분간 지속되었고 시료 사이 에서의 purge도 3 분간을 유지하였다. Syringe purge는 3 초 를 유지한 후 thermostatted tray holder에 놓은 후 head space syringe를 사용하여 $2.5 \mathrm{~mL}$ 취하였다. 시료는 자동 시료채취기가 연결된 전자코(SMart Nose300, SMart Nose, Marin-Epagnier, Switzerland)로 분석하였다. 분석에 사용된 전자코는 질량분석기(Quadrapole Mass Spectrometer, Balzers Instruments, Marin-Epagnier, Switzerland)가 연결되어 있으 며 휘발성 물질들은 $70 \mathrm{eV}$ 에서 이온화시켜 180 초 동안 생 
성된 이온물질을 사중극자(quadrupole)질량 필터를 거친 후 특정 질량 범위 $(10-200 \mathrm{amu})$ 에 속하는 물질을 정수단 위로 측정하여 channel수로 사용하였다. 각각의 시료는 4 회 반복을 실시하였다.

\section{판별함수분석}

판별함수분석(DFA; discriminant function analysis)은 휘 발성 향기 성분으로부터 생성되는 150 여개의 ion fragment 중 이온화되어 얻어진 분자들의 질량별 검출량을 기준으 로 각 시료 간에 차별성이 높은 20-30여개의 fragments $(\mathrm{m} /$ z)그룹을 독립변수로 선택하여 해당 intensity 값을 이용하 여 다음의 식에 따라서 판별함수분석(DFA)을 실시하여 종 속변수에 영향을 주는 독립변수를 검정하였다.

$$
\mathrm{DF} 1=\mathrm{B}_{0}+\mathrm{B}_{1} \mathrm{X}_{1}+\mathrm{B}_{2} \mathrm{X}_{2}+\mathrm{B}_{3} \mathrm{X}_{3} \cdots+\mathrm{B}_{\mathrm{n}} \mathrm{X}_{\mathrm{n}}
$$

$\mathrm{DF} 1$ 는 판별함수값, $\mathrm{B}_{\mathrm{o}}$ 는 판별상수, $\mathrm{B}_{\mathrm{i}}$ 는 판별함수계수, $\mathrm{X}$ 는 각 fragment의 $\mathrm{amu}$ 값에서의 intensity(독립변수)를 나 타낸다.

이들 독립변수 중에서 종속변수를 예측할 수 있는 판 별함수 값은 DF1(discriminant function first score), DF2 (discriminant function second score), DF3 DFn으로 나타 내었다. 여러 독립변수들 중에서 종속변수에 영향력을 주 는 순서를 기준으로 DF1과 DF2를 정하였고, 주로 이 2가 지의 종속변수를 이용하여 열처리 정도와 저장기간과의 관계를 해석하였다.

\section{통계분석}

각 시료의 Discriminant Function Analysis(판별함수분석) 결과 얻은 판별함수 값을 이용하여 시료간의 차별성을 분 석하였다. 이때 사용된 소프트웨어는 SMart Nose statistical analysis software를 사용하였다

\section{결과 및 고찰}

냄새 또는 휘발 성분의 생성은 여러 가지 요인에 의해 서 발생이 된다. 함께 존재하는 여러 가지 미생물들의 생 리작용에 의해서 생성되기도 하며 함께 구성하고 있는 지 방성분의 산패과정에 의해서도 발생되기도 할 뿐만 아니 라 열처리 과정에 의해서도 화학적인 반응이 일어나 다양 한 휘발성분이 생성되기도 한다. 또 저장 중 상기 반응들 이 복합적으로 작용하여 일어나기도 한다. 판별분석은 독 립변수의 특성을 바탕으로 불확실한 판단을 내린 종속변 수의 판단과 결정이 어느 쪽으로 선택한 것인지를 분석해 주는 통계분석 기법이다. 따라서 판별함수는 주어진 독립 변수의 특성을 바탕으로 종속변수의 변화와 판단의 방향 을 예측하는 것이기 때문에 독립변수의 선별이 무엇보다 도 중요하다.
본 연구에서 전자코에 의해서 측정한 휘발성분들은 각 각의 ion fragments 분해되어 이들이 나타낸 intensity값들 이 독립변수로 활용되고 독립변수의 특성을 함수관계로 규정하여 그 함수 중 어느 것이 종속변수의 변화에 영향 을 미치는가를 가려주는 판별분석의 공식이다. 이 공식을 통해 판별함수와 결정계수 $\left(\mathrm{r}^{2}\right)$ 를 구하여 결정계수 값이 높 은 ion fragment $60,91,92,93$ 등이 가장 영향을 미치는 것으로 나타났으며 결정계수 값이 높은 ion fragment를 바 탕으로 판별함수분석을 통해 $\mathrm{DF} 1, \mathrm{DF} 2$ 등의 값들을 얻었 다. 이 판별함수 값을 이용하여 열처리 강도와의 관계, 저 장기간 중 품질변화와의 관계, 보존온도 별 품질변화 관 계를 연구하고자 하였다.

\section{주요 휘발성분들}

Fig. 1은 전자코에 연결된 질량분석기로 분석한 우유 휘 발성분들의 10-200 amu 범위에서 측정된 ion framents 들 의 mass spectrum이다. 우유에서 휘발되는 향기 성분 중 차이가 많이 나는 주요 ion fragment들의 amu는 60,91 , 92,93 이었다. $40 \mathrm{amu}$ 이하에서 나타난 fragment $(\mathrm{m} / \mathrm{z})$ 는 공 기 중에 포함된 성분에 해당되는 것이므로 40-200 amu 내 에서 나타나는 intensity의 차이를 정리한 결과 Table 1에 서 보는 바와 같이 시유의 열처리 조건에 따라 주요 ion fragment들의 감응도 값에 차이가 뚜렷하였다.

Table 1에서 시유의 $60,91,92,93 \mathrm{amu}$ 값을 비교해 보 면, LTLT 제품의 휘발성물질의 intensity는 다른 열처리 제 품에 비하여 비교적 낮은 감응도를 나타냈다. 반면 HTST 제품의 경우에는 LTLT에 비해 intensity값이 모두 높은 것 으로 나타났다. 가장 높은 열처리를 한 UHT 제품도 LTLT, HTST 제품보다 모두 높은 수치를 나타내었다. 이 결과에 서 보면 고온에서 열처리 한 제품이 휘발성 물질의 ion fragment의 intensity 값이 큰 것을 알 수 있었다. 이와 같 은 결과는 시료구입 시점을 고려해 볼 때 신선한 상태의 시유를 시료로 측정한 결과이기 때문에 가열단계에서 생 성된 휘발성 성분의 차이가 잘 반영한 것으로 판단된다.

Rovner(2006)와 Al-Attabi(2009)의 연구결과에 의하면 높 은 온도에서 가열처리를 할수록 황 함유물의 일부 ion fragment가 증가하였다고 하였으나, 본 연구에서 사용한 범위의 $\mathrm{amu}$ 에서 측정된 결과인지는 비교할 수 없었다. Iwatsuki 등(1999)은 열처리를 달리한 시유의 향기 성분을 $\mathrm{GC} / \mathrm{MS}$ 와 aroma extract dilution analysis를 이용하여 분석 한 결과 높은 온도에서 열처리 할수록 2-pentannone, 2heptaone, 2-nonanone, 2-undecanone 등이 많이 생성되어 열처리가 다른 우유간의 향기성분 차이가 있음을 발표한 바 있다. 그러나 UHT제품의 경우에는 휘발성이 높고 열 과 산화에 민감하여 감지되는 성분의 양이 미량이기 때문 에 향기성분을 검출하는데 한계점을 보였다고 하였다. 본 연구에서 높은 온도에서 가열처리를 할수록 intensity가 증 


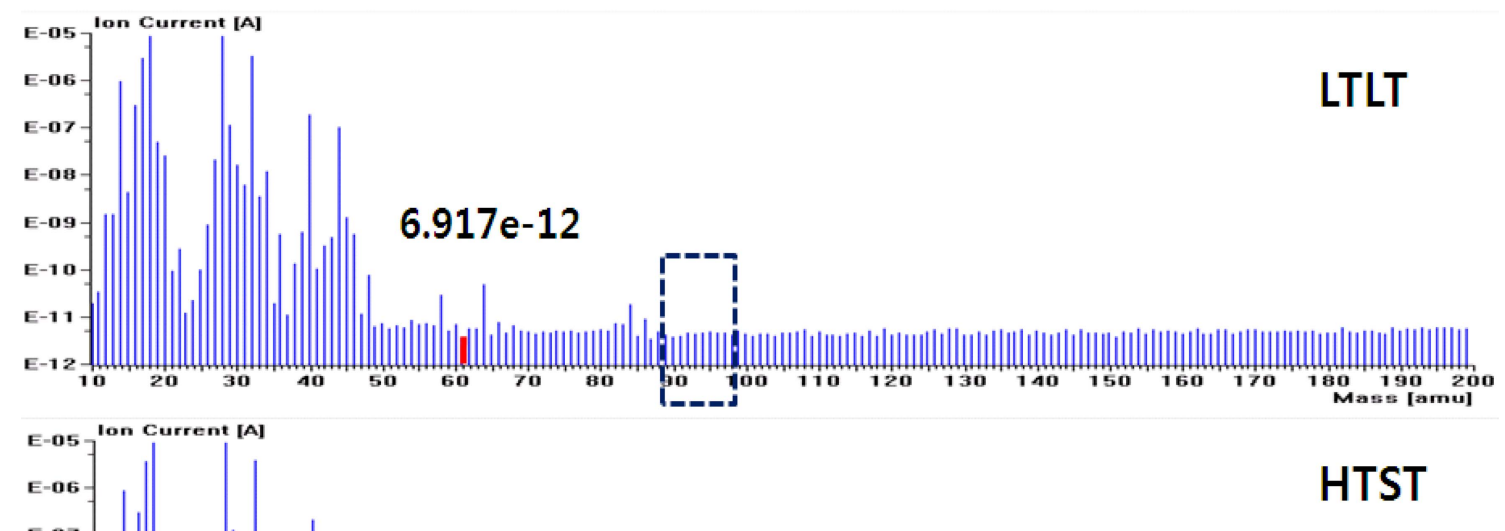

$1.080 \mathrm{e}-11$
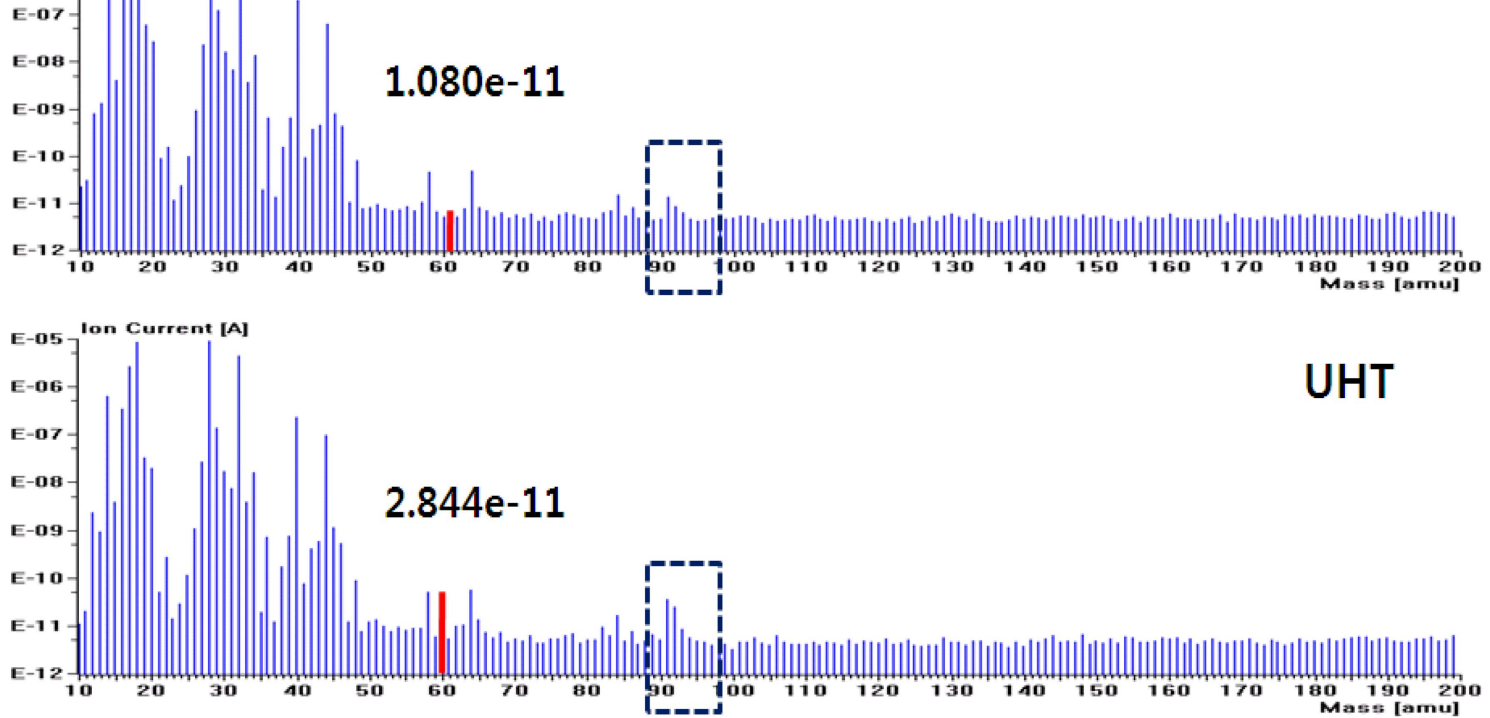

Fig. 1. Ion mass spectrums of three different types of milk analyzed by MS-e-Nose.

Table 1. Responses of ion fragments of flavor materials from the market milk samples analyzed by MS-e-Nose

\begin{tabular}{|c|c|c|c|c|c|c|c|c|}
\hline \multicolumn{9}{|c|}{ Response by electronic nose $\left(\times 10^{11}\right)$} \\
\hline \multirow{2}{*}{ amu } & \multirow{2}{*}{$\frac{\text { LTLT }}{\mathrm{B}}$} & \multicolumn{3}{|c|}{ HTST } & \multicolumn{4}{|c|}{ UHT } \\
\hline & & $\mathrm{C}$ & A & $\mathrm{D}$ & $\mathrm{E}$ & $\mathrm{F}$ & $\mathrm{G}$ & $\mathrm{H}$ \\
\hline 60 & $0.64 \pm 0.035$ & $1.10 \pm 0.027$ & $0.65 \pm 0.007$ & $0.71 \pm 0.006$ & $2.897 \pm 0.01$ & $1.87 \pm 0.012$ & $1.93 \pm 0.032$ & $0.72 \pm 0.096$ \\
\hline 91 & $0.41 \pm 0.054$ & $2.15 \pm 0.031$ & $1.1 \pm 0.041$ & $0.73 \pm 0.01$ & $3.539 \pm 0.077$ & $1.65 \pm 0.068$ & $1.56 \pm 0.026$ & $1.43 \pm 0.010$ \\
\hline 92 & $0.48 \pm 0.036$ & $1.46 \pm 0.022$ & $0.86 \pm 0.045$ & $0.59 \pm 0.056$ & $2.453 \pm 0.016$ & $1.18 \pm 0.06$ & $1.49 \pm 0.043$ & $1.46 \pm 0.034$ \\
\hline 93 & $0.40 \pm 0.036$ & $0.52 \pm 0.020$ & $0.43 \pm 0.041$ & $0.53 \pm 0.052$ & $0.84 \pm 0.036$ & $0.46 \pm 0.03$ & $0.58 \pm 0.032$ & $0.42 \pm 0.027$ \\
\hline
\end{tabular}

가하는 $60,91,92,93 \mathrm{amu}$ 의 ion fragments가 어떤 물질 로부터 분해된 것인가는 이 연구에서 확인하지 않았으나, 이와 같은 한계점은 Ampuero 등(2002)이 MS-전자코를 이 용하여 우유 오염물질 $\mathrm{TMA}$ 에 해당되는 $59 \mathrm{amu}$ 의 정량 적 분석기법을 제시한 것과 같이 추가적인 연구가 이루어 진다면 각 $\mathrm{amu}$ 에 해당하는 휘발성 성분에 대한 검출 및 동정이 가능할 것으로 보인다. UHT제품과 같이 높은 열 처리로 나타나는 극미량의 휘발성 물질의 조성 변화에 대 한 MS-전자코를 통한 연구는 아직 미흡한 실정이므로 향 후 이에 대한 연구가 요구되고 있다.

\section{판별함수 값과 가열 온도 및 보존온도}

가열온도를 달리한 각 시료유의 판별함수 값 $\mathrm{DF} 1$ 과 $\mathrm{DF} 2$ 를 이용하여 도식한 그림은 Fig. 2와 같다. 이 결과는 전 자코를 이용하여 얻은 intensity를 판별함수분석기법으로 통계 처리하여 나타낸 것이다. 그 중에서 가장 영향력이 큰 판별함수 값인 $\mathrm{DF} 1$ 과 $\mathrm{DF} 2$ 를 중심으로 각 시유의 판 별함수를 분석한 결과 Fig 2에서 보는 바와 같이 LTLT(B), $\operatorname{HTST}(\mathrm{A}, \mathrm{C}, \mathrm{D}), \mathrm{UHT}(\mathrm{E}, \mathrm{F}, \mathrm{G}, \mathrm{H})$ 각 제품이 열처리 조건 에 따라 뚜렷한 분리가 이루어졌다.

LTLT 제품은 DF2(y축) 가장 위쪽에 위치하였고 HTST, UHT 순으로 아래쪽으로 배열되는 현상을 보였다. 단, 


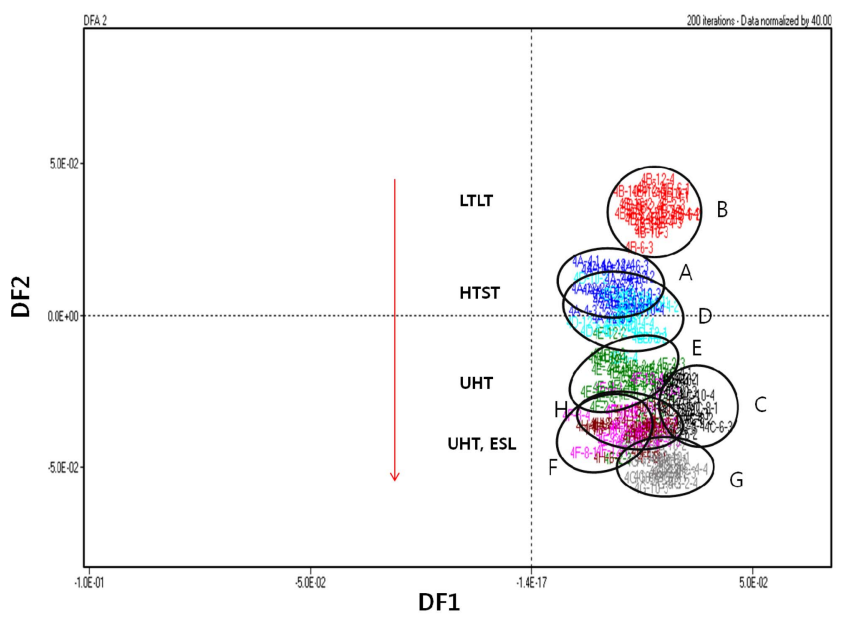

Fig. 2. Discriminant function analysis of the obtained data for maket milk samples using MS based electonic nose. Theose were treated with different thermal condition.

HTST 제품인 C제품은 UHT 제품 지역에 출현하여 예외 적인 결과를 나타내었다. 한편 동일한 UHT 온도조건으로 열처리 한 우유를 무균적 개념의 공정으로 저장하면서 충 진(ESL) 하였는지, 아니면 열처리는 UHT 처리를 하고 별 도의 무균적 개념의 공정을 하지 않고 충진하는가에 따라 서 $\mathrm{DF} 2$ 값의 차이가 있는지 확인하고자 하였으나 두 UHT 제품 간에는 차이가 없었다.

이 결과에 의하면 판별함수 값 $\mathrm{DF} 1$ 에 의해서는 열처리 조건에 따라 차별성이 뚜렷하게 구분되지는 않았고, 반면 판별함수 값 $\mathrm{DF} 2$ 에 의하여 $\mathrm{B}, \mathrm{A}, \mathrm{D}, \mathrm{E}, \mathrm{C}, \mathrm{H}, \mathrm{F}, \mathrm{G}$ 의 순 서로 그 값이 양의 방향에서 음의 방향으로 배열되어 열 처리 조건에 따른 구분이 가능하였다. 즉 열처리온도에 따 라 DF2 값이 영향을 받아 낮은 온도에서 열처리 받은 시 료유의 DF2 값은 위쪽에 자리(양의 값)를 차지하였고 높 은 온도에서 열처리 받은 시료유의 DF2 값은 아래쪽(음

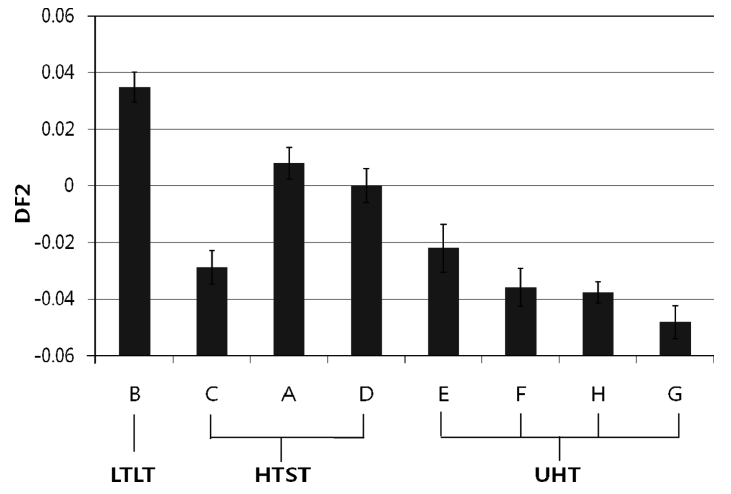

Fig. 3. DF2 scores of the market milk samples treated at different thermal conditions.

의 값)으로 이동하는 경향을 보여주었다. 이 결과를 결정 계수를 구하여 확인한 결과 $\mathrm{DF} 1$ 의 $\mathrm{r}^{2}$ 값은 $0.9895(\mathrm{~F}=2154.7)$ 이었으며 $\mathrm{DF} 2$ 의 $\mathrm{r}^{2}$ 값이 $0.9861(\mathrm{~F}=1625.4)$ 으로서 $\mathrm{DF} 1$ 과 $\mathrm{DF} 2$ 모두 높은 상관관계를 나타내었다.

판별함수 값 $\mathrm{DF} 2$ 는 가열처리 조건에 따라 일정한 방향 으로 변화하는 경향을 보인 결과를 Fig. 3을 통해서 확인 해 보면 더욱 뚜렷하다. 따라서 DF2값으로 나타난 향기물 질은 가열온도에 따라서 변화하는 성분으로 파악되었다. 이러한 결과는 시유의 가열단계에서 어떤 조건의 열처리 가 이루어졌는지를 확인하는 품질관리기법으로서 MS-전 자코 분석기술의 활용성을 가능케 해주는 의미가 있는 성 과라고 할 수 있다.

가열처리 조건이 다른 시유 제품을 일정 보존온도에서 저장하면서 저장기간에 따른 향기패턴 변화와 그 판별함 수 값 $\mathrm{DF} 1$ 과의 관계를 보면 Fig. 4-6과 같다.

LTLT와 HTST, UHT 공정을 거친 제품을 $4^{\circ} \mathrm{C}$ 에서 10 일 간 저장한 결과는 LTLT 제품의 경우(Fig. 4-a) 저장기간에 따라 DF1값이 영향을 받아 양의 방향에서 음의 방향으로
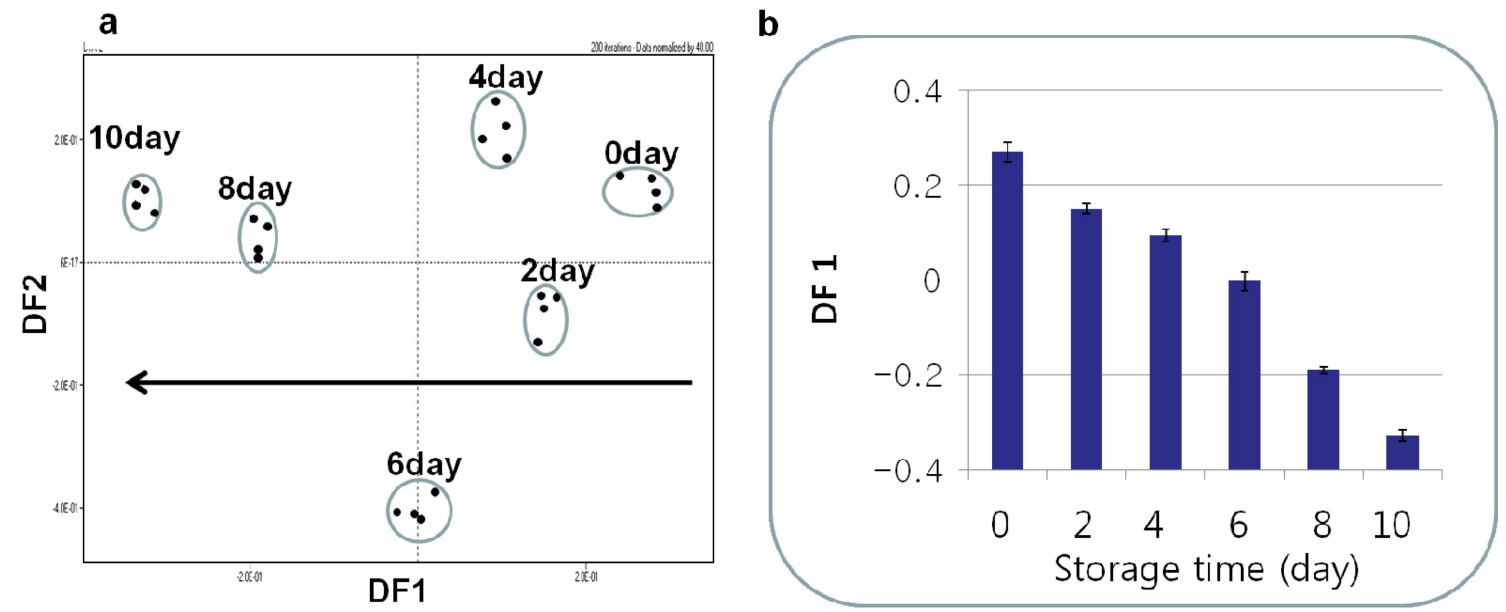

Fig. 4. Discriminant function analysis of the obtained data for the LTLT milk using MS based electronic nose (a). Those were stored $4^{\circ} \mathrm{C}$ for $10 \mathrm{~d}$ (a). Relationship between DF1 and storage time for the LTLT milk (b). 

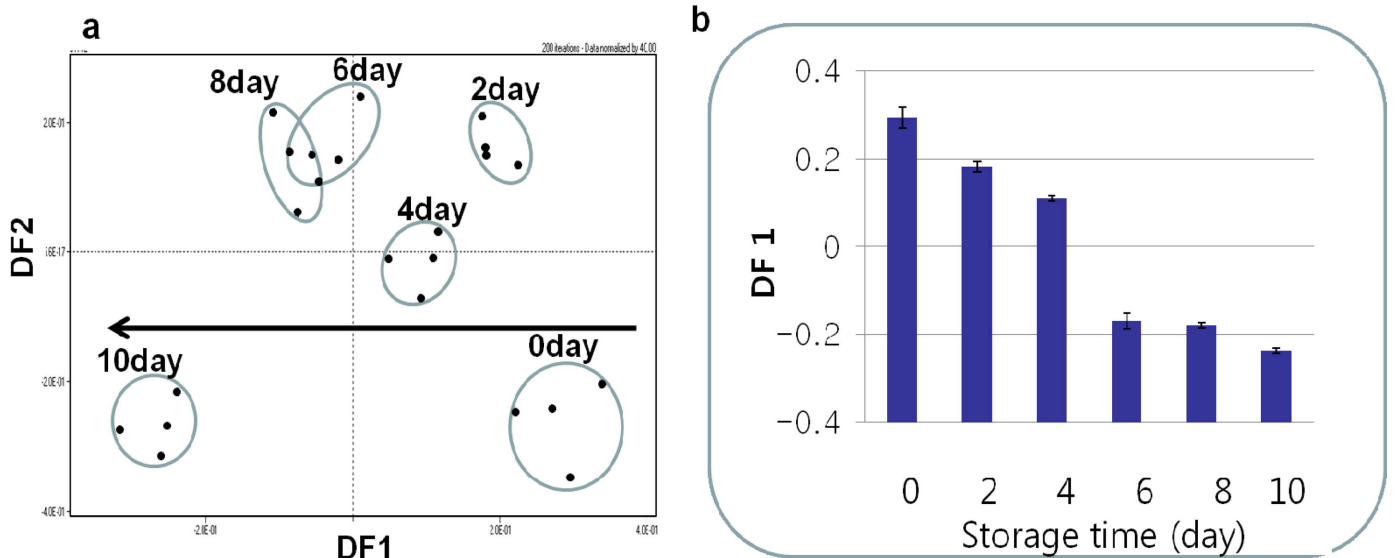

Fig. 5. Discriminant function analysis of the obtained data for the HTST milk using MS based electronic nose (a). Those were stored $4^{\circ} \mathrm{C}$ for $10 \mathrm{~d}$ (a). Relationship between DF1 and storage time for the HTST milk (b).

일정하게 향기 패턴이 변화하고 있음을 알 수 있었다. 이 는 저장일수와 $\mathrm{DF} 1$ 의 상관관계 $\left(\mathrm{r}^{2}=0.9965, \mathrm{~F}=812.74\right)$ 가 매 우 높다는 사실을 보여주고 있다. 이를 막대그래프로 표 현한 Fig. 4-b를 보면 저장일 수가 증가함에 따라 DF1의 값이 일정하게 감소하는 경향을 분명하게 확인할 수 있었 다. HTST처리한 우유(Fig. 5-a)는 저장일 수가 증가함에 따라 LTLT제품과 마찬가지로 DF1의 영향을 받아 양의방 향에서 음의 방향으로 일정하게 변화하여 $\mathrm{DF} 1$ 값이 점차 낮아지는 일정한 상관관계 $\left(\mathrm{r}^{2}=0.9965, \mathrm{~F}=1025.1\right)$ 를 나타내 었다(Fig. 5-b). UHT처리한 우유도 높은 상관관계 $\left(\mathrm{r}^{2}=0.9911\right.$, $\mathrm{F}=315.43)$ 를 보이며 저장일수가 증가함에 따라 향기패턴 이 DF1의 양의 방향에서 음의 방향으로 변화하였다.

각 시유 제품별로 저장일수에 따른 $\mathrm{DF} 1$ 값을 막대그래 프로 나타낸 그림(Fig. 4-b, Fig. 5-b, Fig. 6-b)을 보면, 저 장 초기에 비하여 저장일 수가 증가함에 따라 DF1의 값 이 변화하는 정도가 비교적 커지는 것을 알 수 있다. 따 라서 $\mathrm{DF} 1$ 값으로 나타난 향기성분의 변화량은 저장기간과 관련성이 높은 것으로 파악되었다. 이와 같은 결과는 LTLT,
HTST, UHT 열처리한 우유를 15 일간 저장하여 이취 정도 를 관능검사를 통해 측정하였을 때 초기에는 변화가 미세 하지만 저장 일수가 증가할수록 그 변화하는 정도가 커졌 다는 Kwon 등(1998)의 결과와 유사한 것이다.

\section{저장기간에 따른 품질 변화량 예측}

위의 결과들을 살펴보면 MS-전자코 분석기법이 기존의 관능적 품질검사를 보완하여 시유의 품질관리기법으로 적 용할 수 있는지 또는 보존온도에 따른 DF1과 DF2의 변 화량으로 저장기간에 따른 품질 변화량을 예측할 수 있는 지에 대한 응용기술로 적용이 가능 할 것으로 보인다.

시유의 보존온도별로 저장기간에 따른 품질 변화랑을 알 아보기 위하여 4,7 및 $10^{\circ} \mathrm{C}$ 에 저장하면서 향기 패턴을 MS-전자코로 분석한 결과는 Fig. 7-9와 같다. 그 결과 일 정 온도조건에서 저장기간을 구분하는 지표로서 DF1값을 적용해 보면, 가열처리에 의해 생성된 휘발성분과 저장기 간 중에 생성되는 휘발성분의 패턴에 차이가 있음을 이해 할 수 있다.

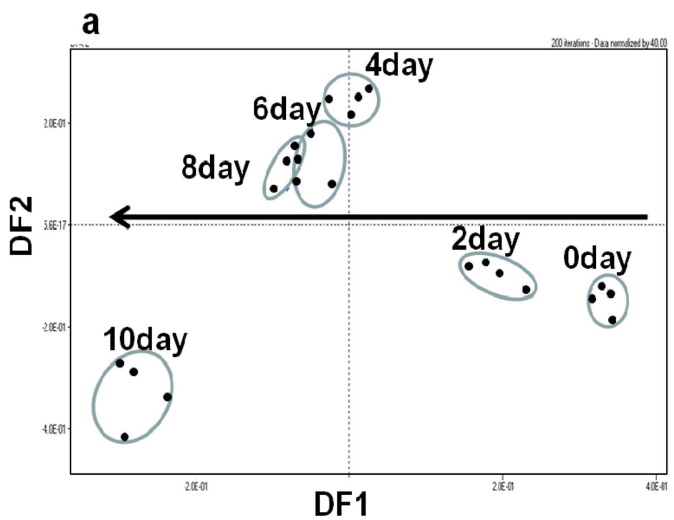

b

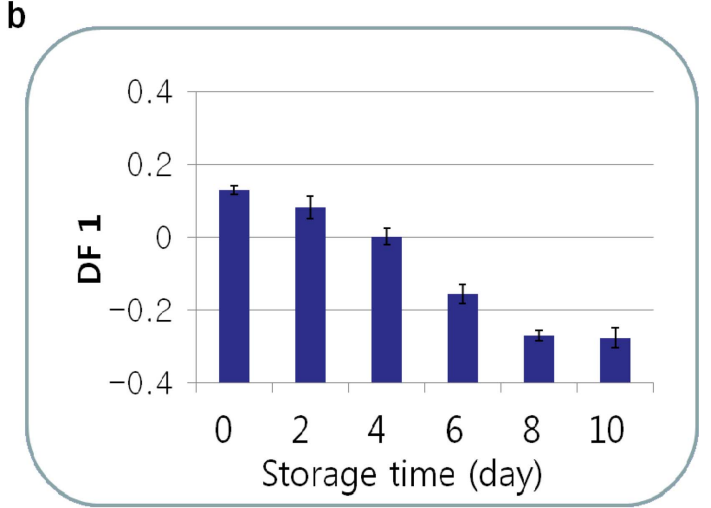

Fig. 6. Discriminant function analysis of the obtained data for the UHT milk using MS based electronic nose (a). Those were stored $4^{\circ} \mathrm{C}$ for $10 \mathrm{~d}$ (a). Relationship between DF1 and storage time for the UHT milk (b). 

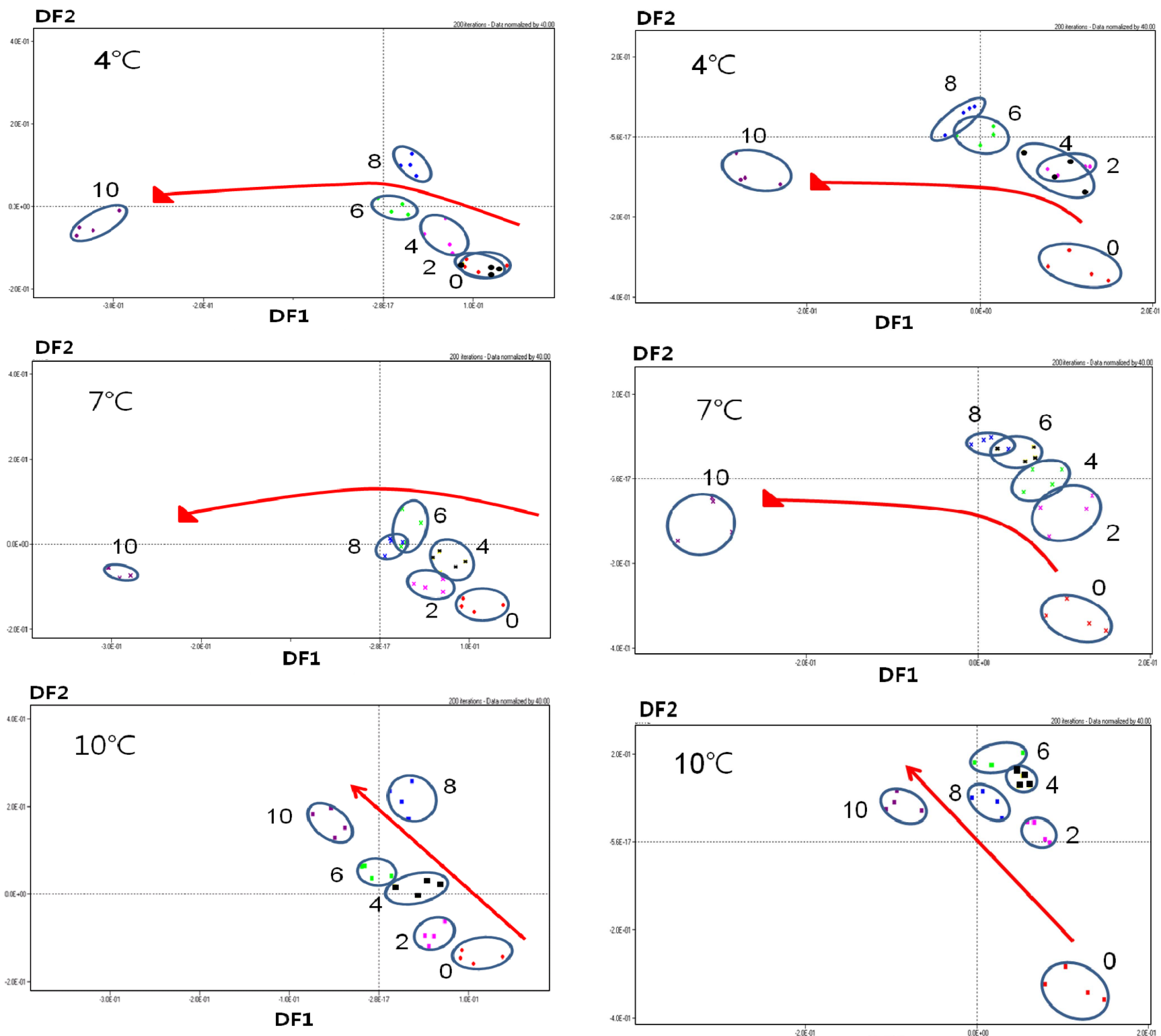

Fig. 7. Discriminant function analysis of the obtained data for the LTLT milk using MS based electronic nose. Those were stored for at various temperatures $10 \mathrm{~d}$.

Fig. 7은 보존 온도를 달리하여 저장한 LTLT 우유의 품 질 변화량을 $\mathrm{DF} 1$ 과 $\mathrm{DF} 2$ 의 변화 패턴으로 보여주는 그림 이다. $4,7^{\circ} \mathrm{C}$ 에서는 저장일수가 증가할수록 $\mathrm{DF} 1$ 은 양의 방향에서 음의 방향으로 이동하는 것을 알 수 있다. 반면 에 $10^{\circ} \mathrm{C}$ 에서는 저장 일수가 증가하면서 $\mathrm{DF} 1$ 이 양의 방향 에서 음의 방향으로 이동하는 것은 같은 현상이나 $\mathrm{DF} 2$ 의 진행 방향이 $4,7^{\circ} \mathrm{C}$ 와는 달리 양의 방향으로 이동하는 점 이 다른 것을 알 수 있다.

이러한 결과는 $\mathrm{DF} 1$ 과 $\mathrm{DF} 2$ 모두 저장기간에 따른 변화 뿐만 아니라 보존온도에 의한 변화도 함께 예측할 수 있 다는 사실을 보여주는 것이다. 이와 같은 결과는 HTST 제품(Fig. 8)에서도 유사한 경향이었다. 반면에 UHT 제품 (Fig. 9)은 각 보존온도에 따른 휘발성 성분 패턴의 변화

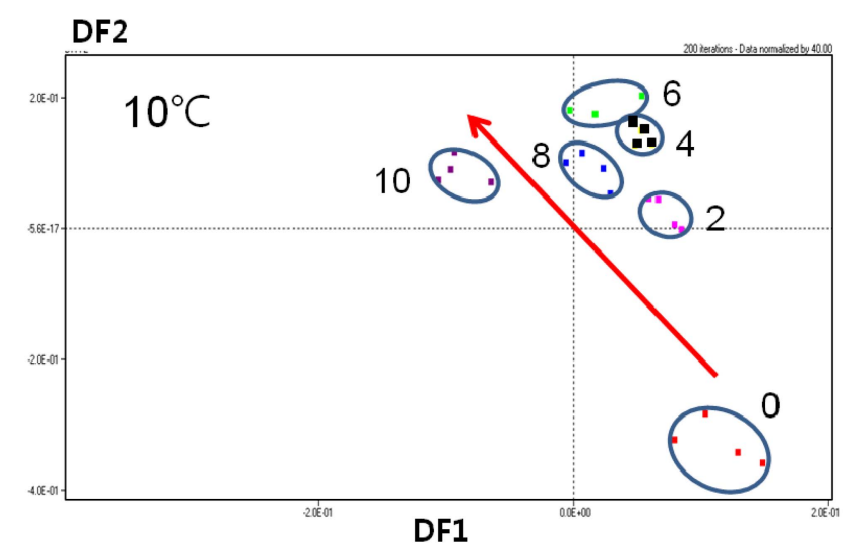

Fig. 8. Discriminant function analysis of the obtained data for the HTST milk using MS based electronic nose. Those were stored at various temperatures for $10 \mathrm{~d}$.

가 모두 DF1이 양의 방향에서 음의 방향으로 변화하는 경 향을 나타냄으로써 보존온도에 따른 품질변화의 차이를 구분하기 어려운 것으로 보였다. 그 이유로는 LTLT나 HTST 제품의 경우 가열단계에서 미생물이 완전히 사멸되 지 않고 낮은 보존온도이지만 저장기간 중에 생존 미생물 에 의한 생장이 개시되면서 휘발성 성분이 생성된 때문으 로 사료된다. 그러나 미생물이 완전히 사멸되는 가열조건 에서 처리된 UHT 제품의 경우에는 미생물이 존재하지 않 으므로 미생물에 의한 영향은 없다고 간주할 수 있기 때 문에 가열처리 공정 중 생성된 휘발성분이나 내열성 효소 들에 의한 변화에 의해서만 이취가 생성된 것으로 사료되 며, 그러한 변화는 보존 온도에 따라 별다른 차이를 보이 


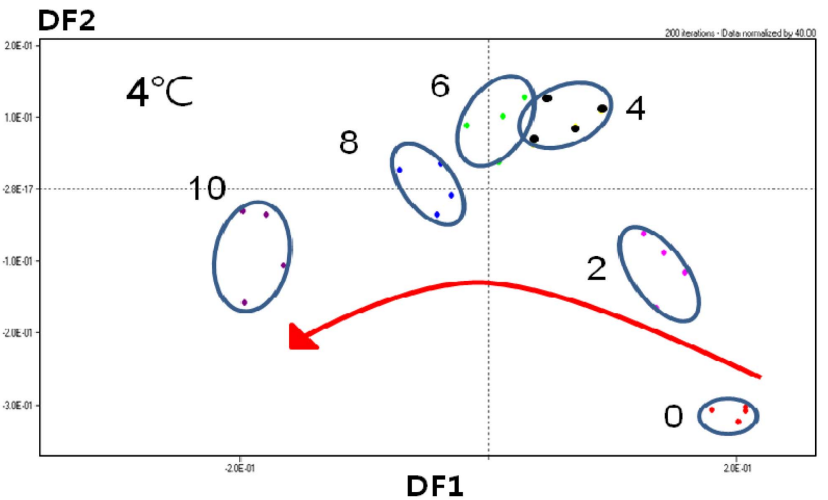

DF2

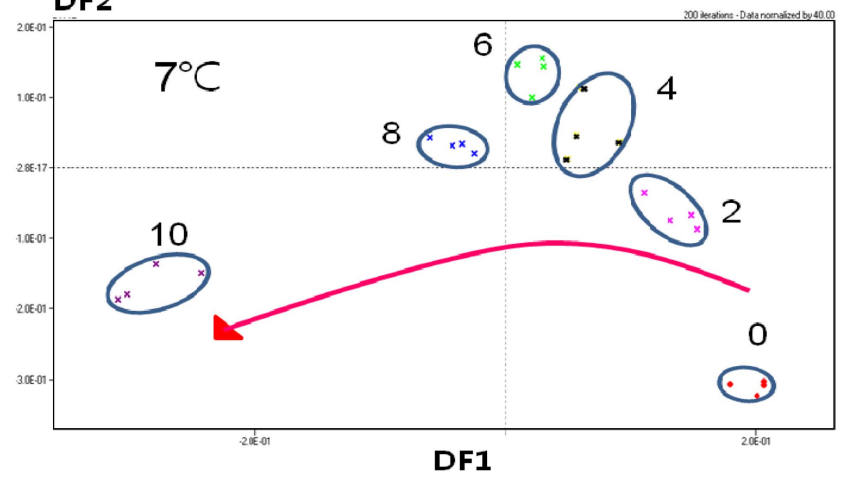

DF2

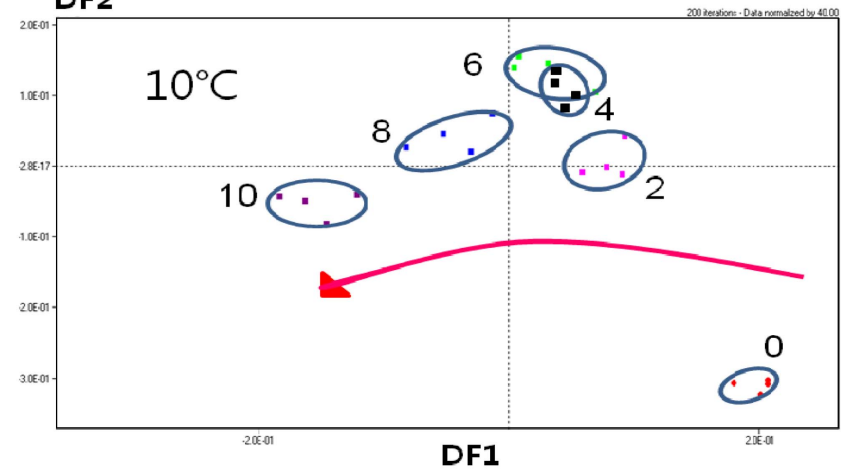

Fig. 9. Discriminant function analysis of the obtained data for the UHT milk using MS based electronic nose. Those were stored at various temperatures for $10 \mathrm{~d}$.

지 않았던 것으로 나타났다.

즉 LTLT, HTST 제품은 낮은 보존 온도 $\left(4,7^{\circ} \mathrm{C}\right)$ 에서는 저장기간에 따른 변화를 나타내는 DF1의 영향을 주로 받 는 것으로 나타났지만, 높은 보존온도 $\left(10^{\circ} \mathrm{C}\right)$ 에서는 저장 기간에 따른 변화뿐 아니라 열처리에 따른 경향을 보이 는 $\mathrm{DF} 2$ 의 영향도 동시에 받는 것으로 나타났다. 이러한 결과는 두 제품에 있어서는 전자코 분석을 통하여 미세 한 휘발성 성분의 변화량을 산출하게 된다면 유효 저장 기간의 도출이 가능한 것으로 나타났다. 반면에 UHT 제 품은 저장기간에 따른 변화를 나타내는 DF1의 영향을 받 지만 보존 온도에 따른 영향은 거의 받지 않기 때문에 보존온도에 따른 유효 저장기간의 도출은 어려운 것으로
사료된다.

Chung 등 (2002)은 $5,10,15^{\circ} \mathrm{C}$ 로 온도를 달리하여 저장 한 $\mathrm{UHT}$ 우유의 변화를 관능 검사한 결과 $10^{\circ} \mathrm{C}$ 에서 10 일 간 저장한 우유는 풍미 및 외관상 변화가 없었으나 15 일 에는 풍미가 미세하게 감지되었으며, $15^{\circ} \mathrm{C}$ 에서 10 일간 저 장한 우유는 이취가 미세하게 감지되었고 15 일에는 이취 가 확실히 감지되었다고 하였다. 본 연구에서는 $15^{\circ} \mathrm{C}$ 의 보존온도를 설정하지 않았으나 UHT 우유를 $10^{\circ} \mathrm{C}$ 에 저장 하였을 때 10 일까지는 별 다른 차이가 없었다는 결과와 동일한 결과로 보인다. 저장 초기에는 UHT제품의 휘발성 분이 많이 생성된 것으로 나타났지만 저장기간이 지남에 따라서 우유의 향기성분이 변하는 것은 살균 전 원유의 미생물학적 품질과 관련성이 매우 높으며, 내냉성 미생물 에 의해서 생산된 내열성 효소들이 파괴되지 않고 일부 잔존하여 단백질이나 지방의 분해가 일어났기 때문일 것 으로 추측된다.

\section{요 약}

본 연구는 MS-전자코 분석기술과 판별함수분석을 응용 하여 우유의 가열조건 및 보존온도에 따른 저장기간을 예 측할 수 있는 가능성을 알아보고자 실시하였다. MS-전자 코 분석에 의하여 mass spectrum에서 검출된 우유의 휘발 성 성분들은 $а т и$ 60, 91, 92 및 93에서 얻은 ion fragments 들의 intensity로 구분이 가능하였다. 이 범위의 $a m u$ 에서 검출된 휘발성 물질들의 검출 수준은 매우 낮은 수준이었 으나, 가열처리 조건에 따라 휘발성 물질의 검출 수준의 차이가 LTLT $\rightarrow \mathrm{HTST} \rightarrow \mathrm{UHT} \rightarrow$ 멸균유 순으로 뚜렷하게 나 타났다. 검출된 성분들의 intensity값을 판별함수 값으로 변 환하여 보존온도, 저장기간 및 열처리 조건과의 관련성을 알아본 결과 판별함수 값 $\mathrm{DF} 1$ 은 저장기간에 따라 변화하 는 휘발성 성분의 변화량과 높은 상관관계을 보였으며, 4 , 7 , 및 $10^{\circ} \mathrm{C}$ 의 보존 온도에서 $\mathrm{r}^{2}$ 값은 각각 $0.9965,0.9965$ 및 0.9911 이었다. 반면에 판별함수 값 $\mathrm{DF} 2$ 는 가열온도에 따라 변화하는 휘발성 성분의 변화량과 높은 상관관계를 보였으며, $4^{\circ} \mathrm{C}$ 의 보존 온도에서 $r^{2}$ 값은 0.9861 이었다. 따 라서 MS-전자코 분석기술과 판별함수분석을 응용하여 우 유의 가열조건 및 보존온도에 따른 저장기간을 예측할 수 있는 새로운 품질관리 모델시스템 구축이 가능함을 확인 할 수 있었다.

\section{감사의 글}

본 연구는 2009년 국립수의과학검역원에서 시행한 용역 연구사업(Z-FS02-2009-09-02)의 연구 결과이며, 연구비 지 원에 감사 드립니다. 


\section{참고문헌}

1. Al-Attabi, Z.D., Arcy, B.R., and Deeth, H.C.(2009) Volatile sulphur compounds in UHT milk. Critical Rev. Food Sci. Nutri. 49(1), 28-47.

2. Ampuero, S., Zesiger, T., Gustafsson, V., Lunden, A., and Bosset, J.O. (2002) Determination of trimethylamine in milk using an MS based electronic nose. Eur. Food Res. Technol. 214, 163-167.

3. Barlet, P. N., Elliott, J. M., and Gadner, J. W. (1997) Electronic nose and their application in the food industry. Food Technol. 51(12), 44-48.

4. Choi, H. D. (1995) Use and development of sensation sensor. Bulletin Food Technol. 8, 122-131.

5. Chung, C. I., Kim, K. T., Cho, N. Y., Jung, M. J., Oh, H. S., and Lee, G. (2002) Comparison of the keeping quality of UHT pasteurized milks in Korea. Korean J. Food Sci. Ani. Resour. 22(3), 247-251.

6. Chung, S. J., Lim, C.R., and Noh, B.S. (2008) Understanding the sensory characteristics of various types of milk using descriptive analysis and electronic nose. Korean J. Food Sci. Technol. 40(1), 47-55.

7. Elliker, P. R., Sing, E. I., Christensen, L. J., and Sandine W. E. (1964) Psychrophilic bacteria and keeping quality of pasteurized dairy products. J. Milk Food Technol. 27, 69-75.

8. Hodgins, D. and Simmonds, D. (1995) Sensory technology for flavor analysis. Cereal Foods World, 40, 186-191.

9. Iwatsuki, K., Mizota, Y., and Kubota, T. (1999) Evaluation of aroma of pasteurized and UHT processed milk by aroma extract dilution analysis. J. Japanese Soc. Sci. Tech. 46(9), 587-597.

10. Kim, S. M. and Noh, B. S. (2002) Characteristics of shelflife of soybean curd by electronic noses. Korean J. Sci. Agric. Machinery, 27(3), 241-248.

11. Kwon, S. H., Ahn, J. J., and Kwak, H. S. (1998) Quality changes in various heat-treated market milks during storage. J. Korean Dairy Technol. Sci. 16(2), 90-97.

12. Said, L., Sandrine, B., Sonia, C., and Eric, C. (2005) Shelf life determination by electronic nose: application to milk. Sensors and Actuators B. 106, 199-206.

13. Rovner, S. L. (2006) Processing milk under pressure-low temperature treatment keeps unsavory volatiles in check. Chem. Eng. News, Food Sci. Nov. p. 14.

14. Vincent, D. (1999) Electronic nose; principal and application. Nature 402, 351-352.

15. White, C. H., Wilson, J., and Schilling, M. W. (2006) An Investigation of the use of the MicroFoss as an indicator of the shelf life of pasteurized fluid milk. J. Dairy Sci. 89, 24592464.

16. Yang, Y. M., Noh, B. S., and Hong, H. K. (1999) Prediction freshness for milk by the portable electronic nose. Food Eng. Progress 3(1), 45-50.

17. Youn, A. R. (2007) Analysis for cyclodextrins to entrap with hexanal using electronic nose. Korean J. Food Sci. Technol. 39(1), 1-6.

(Received 2010.3.3/Revised 1st 2010.6.27, 2nd 2010.9.12/ Accepted 2010.9.14) 